\title{
EKSPLOITASI WANITA \\ DALAM PERSPEKTIF KAPITALIS
}

\author{
Syamsudin \\ Dosen Fakultas Humaniora dan Budaya UIN Malang
}

\begin{abstract}
ABSTRAK
In globalization era with its free market, to run a business successfully is very hard. Life is very competitive. And a business man, as the owner of the capital, will do everything for the success of his business. Employing women in many sectors of businesses can be a fruitful way. In this case, women have been exploited fully to follow what the business man wants. But they, the women, can't refuse it. Clearly, capitalism has created two classes in society: the capitalist group (capital owner) and the worker group (non capital owner). basically exploitation of women in various of businesses is only one of the ways done by the capitalist to show individualism, to win competition, and to get as many benefits as possible in business. Above all, exploiting women is just one of the ways taken by the capitalist to survive in this competitive-free market. And as far as the capitalist still hold the economic system of the world, women exploitation will never end.
\end{abstract}

\section{A. Pendahuluan}

Belakangan ini diberbagai media massa seperti TV, koran, majalah, dan lain-lain di negeri kita yang tercinta ini dipenuhi berita kontroversi penerbitan majalah Playboy versi Indonesia oleh PT Velvet Silver Media. Diberbagai daerah banyak pihak dari kalangan akademisi dan juga agamis turun kejalan memprotes penerbitan majalah tersebut. " Hari pertama beredarnya majalah Playboy versi Indonesia kemarin disambut baragam reaksi. Meski laris manis dipasaran,kantor majalah tersebut didemo. Kantor majalah yang terletak digedung AAF, Jl. TB Simatupang,kemarin siang diserbu 20 pimpinan cabang Front Pembela Islam (FPI) DKI Jaya. Mereka menuntut agar majalah tersebut ditarik dari peredaran."1

Mereka berpendapat bahwa majalah tersebut banyak menampilkan wanita yang berpose vulgar. Lebih jauh mereka mengungkapkan kalau hal ini tentu saja sangat tidak cocok dengan budaya Indonesia yang mengutamakan sopan santun dan juga menjunjung moralitas dalam setiap sendi kehidupan. Sehingga kalau dibiarkan akan menjadi sangat berbahaya bagi eksistensi generasi muda kita. Menurut Alwi Usman, Ketua Badan Investigasi FPI, ada empat halaman dari majalah itu yang tidak layak dikomsumsi kalangan muda. "Kita sudah melihat majalahnya dan empat halaman artis itu sangat tidak layak untuk adik-adik kita," Ujarnya. "Pernyataan sikap Aliansi Bhineka Tunggal Ika dengas tegas menolak keras maraknya pornografi karena itu adalah sebuah bentuk eksploitasi berlebihan atas seksualitas melalui majalah, buku, film, internet, dll., yang tersebar

\footnotetext{
${ }^{1}$ Jawa Pos edisi 8 April 2006

2 ibid
} 
secara luas dan dengan mudah diakses masyarakat. Itu semua merusak moral bangsa dan melecehkan wanita."

Selain itu, isi majalah itu juga sangat bertentangan dengan ajaran Islam, yang notabene dipeluk oleh sekitar 90\% penduduk Indonesia. Imam S. Nugroho, Ketua Aliansi Jurnalis Independen (AJI) Surabaya, menyatakan "penerbitan majalah Playboy menimbulkan situasi tidak nyaman dalam kehidupan masyarakat. Sebab mayoritas penduduk Indonesia beragama Islam dan sensitif terhadap penerbitan majalah bercitra cabul tersebut." "Penerbitnya, PT Velvet, juga tidak arif dalam melihat situasi dan kondisi masyarakat Indonesia yang agamis. Terbukti mesti ditentang oleh banyak pihak,majalah yang berpusat di Amerika Serikat itu tetap nekat diterbitkan di Indonesia," tandasnya dalam sebuah diskusi publik bertajuk 'Membedah Kontroversi Majalah Playboy di Indonesia' di STIK Surabaya. ${ }^{4}$

Sementara itu Habib Husein, Presiden Ikhwanul Muslimin Indonesia (IMI), menuding penerbitan majalah Playboy Indonesia sebagai bagian dari rencana zionisme internasional dan dunia Barat. "Tidak mampu melawan secara fisik, kaum zionis dan Barat menggunakan majalah Playboy untuk menghacurkan moral bangsa kita”. Tutur Husein di gedung MUI kota Depok, Sabtu (15/4) Malam. ${ }^{5}$

Sebetulnya protes mereka, kelompok yang kontra, telah dimulai semenjak beredarnya issue yang santer terdengar dimasyarakat bahwa majalah "Barat" ini akan terbit dalam versi Indonesia. Namun usaha mereka untuk mencegah penerbitan majalah itu ternyata sia-sia belaka, toh kenyataannya nomor perdana majalah tersebut sudah dapat dijumpai dan dibeli di tempat para penjual koran ataupun agen majalah yang ada dipinggir-pinggir jalan. Sekarang "agak sulit" mendapatkan majalah tersebut. Kabarnya para penjual majalah eceran tersebut takut akan adanya rasia mendadak yang dilakukan oleh petugas keamanan maupun kelompok masyarakat tertentu. "Sejak ramai diberitakan yang mencari majalah Playboy kekios saya sampai puluhan. Tapi terus terang, kalaupun ada saya takut kena sweeping jika menjualnya," Ujar Hasan salah satu agen di bursa koran dan majalah Jl. Pahlawan Surabaya. ${ }^{6}$

Wanita memang diciptakan indah, cantik dan mempesona. Kesempatan ini tidak dilepaskan oleh kaum kapitalis bagi pengembangan usaha mereka. Wanita dan dunia usaha/ bisnis adalah dua hal yang sulit dipisahkan. Hampir bisa dipastikan di setiap bidang bisnis: film, sinetron, telivisi, radio, iklan, perdagangan, dll. selalu melibatkan wanita didalamnya. Selain itu, kaum kapitalis sebenarnya memegang posisi kunci dalam setiap bisnis yang banyak melibatkan kaum wanita tersebut. Dalam konteks ini, artikel ini akan membahas alasan-alasan yang mendasari kaum kapitalis memanfaatkan wanita untuk kepentingan bisnis mereka.

\footnotetext{
${ }^{3}$ Kompas edisi 23 April 2006

${ }^{4}$ Republika edisi 17 April 2006

${ }^{5}$ ibid

${ }^{6}$ ibid
} 


\section{B. Wanita dan Dunia Bisnis}

Dunia bisnis sulit hidup tanpa wanita. Wanita bahkan dijadikan icon. Hampir setiap bidang usaha yang ada dibumi ini pasti melibatkan wanita. Memang wanita dan dunia usaha/ bisnis adalah dua hal yang sulit dipisahkan. Keduanya bagaikan dua gambar dalam satu mata uang logam. Dinas Tenaga Kerja Propinsi Jawa Timur menyatakan bahwa TKI, ditinjau dari jenis kelaminnya, pada triwulan 1-2005 persentase pekerja wanita sebanyak 3.918 orang atau $60,14 \%$ dan pekerja pria sebanyak 2.597 orang atau 39,86\%. Dengan demikian secara prosentase jelas terlihat bahwa jumlah pekerja wanita lebih banyak dari pada pekerja pria. Sebagian besar wanita tersebut bekerja dibidang industri, perdagangan, hotel dan pariwisata, dll. $^{7}$

Wanita memang sudah ditakdirkan menjadi individu yang feminim dan cantik. Tidak seperti pria yang banyak menggunakan rasio dalam berbagai hal, wanita lebih cenderung menggunakan perasaan. Secara fisik mungkin mereka tidak lebih dari pria. Tetapi diluar kekuatan fisik mereka dapat lebih perkasa dari pada pria. Terutama berkaitan dengan kodrat mereka yang telah diciptakan sebagai mahkluk yang mempesona. Dengan kelebihan yang mereka miliki ini, mereka dapat memasuki setiap bidang usaha untuk berkompetisi dengan pria dan bahkan memenangkan kompetisi tersebut. Kebanyakan mereka bergelut dalam sektor jasa dan juga hiburan seperti, bisnis Periklanan, Perfileman/ Sinetron, Pariwisata, Perhotelan dll. Pada dasarnya penggunaan tenaga wanita dalam setiap bidang bisnis yang ada merupakan bagian dari strategi bisnis kaum kapitalis untuk mengeruk keuntungan sebanyak-banyaknya. Hal ini pula yang telah dilakukan oleh sebuah perusahaan pencucian mobil di Dresden Jerman, yang mempekerjakan model perempuan sebagai tukang cucinya. Nama perusahaan itu Erotic Car Wash. "Hanya dengan membayar Rp. 347.000, mobil pelanggan akan dicuci dua model perempuan berpakaian seksi selama 20 menit.” Jelas sang manager. ${ }^{8}$

Yang paling banyak dijumpai menggunakan tenaga wanita adalah bisnis hiburan. Dan juga setiap bidang bisnis yang berkaitan dengan dunia hiburan. Hal ini bisa terlihat ketika kita melihat acara TV. Banyak program yang selalu menampilkan kaum hawa ini. Apakah acara tersebut iklan , sinetron, film, drama, olah raga, "fashion show", gosip, musik, dll. Mereka yang tampil disetiap acara itupun rata-rata adalah wanita yang "cantik". Dalam artian berkulit putih bersih, rambut lurus, body yang menawan, tidak pendek dan kalau bisa warga keturunan. Dengan gaya-gaya mereka yang menawan dan terkadang 'centil', wanita-wanita 'cantik' ini sering kita jumpai dalam setiap acara TV yang ada.

Dalam sebuah acara tertentu, misalnya musik (pop/ dangdut), mereka (para artis/ intertainer) dituntut untuk tampil menarik. Gaya tampilan yang menarik itu mereka representasikan dalam gaya berpakaian maupun bermake-up. Untuk itu mereka kadang-kadang dituntut berpakaian sangat 'sexy' yang sangat menonjolkan sisi feminin mereka. Namun gaya berpakaian yang terlalu feminin tersebut kadang-kadang bukan merupakan keinginan mereka, tetapi lebih pada keinginan sang

\footnotetext{
7 Bank Indonesia, Kajian Ekonomi Regional Propinsi Jawa Timur. Surabaya: Bank Indonesia Surabaya Bidang Ekonomi Moneter (2005)

${ }^{8}$ Jawa Pos edisi 8 Juli 2006
} 
sutradara atau produser. Para sutradara atau produser tersebut berkilah bahwa apa yang dilakukan oleh artis tersebut merupakan tuntutan pasar. Kalau sudah demikian mereka akan menuruti saja kenario yang ada. Hal ini dialami oleh Titi kamal, seorang artis film. Gadis kelahiran 7 Desember 1981 ini sudah terlanjur jatuh cinta dengan skenario film yang ditawarkan sang produser. Sehingga ia tidak mau melepaskan kesempatan yang ada itu begitu saja. "Saya suka banget ceritanya, walaupun masih malu," katanya. ${ }^{9}$

Bagi seorang artis/ intertainer gaya atau model berpakaian merupakan prestise tersendiri. Sebagai seorang profesional, disatu pihak mereka akan menggunakan pakaian yang bisa jadi menambah profesionalitas tetapi dilain pihak dapat juga terlalu feminin yang akan menimbulkan kesan seronok. Namun mereka berkilah bahwa gaya berpakaian mencerminkan sikap profesional mereka terhadap bidang yang mereka geluti, selain itu gaya bagi mereka menjadi penentu keberhasilan sebuah acara. Dalam sebuah pentas musik misalnya, seorang artis, yang hanya dibungkus oleh sehelai kain sutera berwarna merah jambu yang menerawang dan cenderung yang memperlihatkan lekuk tubuhnya, dapat tampil maksimal saat menampilkan goyangan/ jogetan yang erotis. Paduan antara pakaian yang serba seksi serta jogetan sang artis yang meliuk-liuk dengan berbagai macam gaya inilah yang dapat membius beribu pasang mata penonton.

Hal ini bisa kita jumpai dalam hiburan musik dangdut/ pop/ film yang disiarkan oleh berbagai stasiun televisi. Acara-acara tersebut bisa dikatakan sukses sebab bisa menyedot ribuan pasang mata yang terpukau oleh joget/ goyangan sang biduan/ aktris. Ini pula yang akan dialamai Titi, seorang artis, yang kemudian terus menyakinkan diri bahwa apa yang akan dilakukannya nanti bagian dari tuntutan peran semata. Memang tantangan yang didapat dalam film besar ketiganya ini memang tak main-main. Dalam film yang berjudul 'Mendadak Dangdut' itu, selain mangalahkan rasa malu dengan dangdut, Titi dituntut untuk menyanyi, berjoget, dan bermain organ. "Tadinya aku pikir hanya akting,suara orang lain yang mengisi, tapi ternyata nggak," sambungnya. ${ }^{10}$

Banyak yang menilai gaya berpakaian dan juga goyangan artis diatas panggung yang vulgar bisa diklasifikasikan sebagai sesuatu yang berbau "pornoaksi”. Sebab jenis tontonan ini dianggap dapat mempengaruhi pikiran penonton kehal-hal yang berbau seksual. Dan kemungkinan, setelah melihat jenis hiburan semacam itu, pikiran seorang penonton akan tercemar untuk selalu ingat gaya sang artis diatas panggung. Dampaknya, bagi penonton yang tidak kuat "imannya" akan mencari saluran baik yang "legal/ illegal" guna memuaskan nafsu syahwat mereka yang begitu menggelora.

Tetapi ada pula yang berpendapat bahwa apa diakukan oleh sang artis diatas panggung adalah sebuah seni. Mereka berkilah bahwa dalam bisnis hiburan, ini adalah hal yang biasa. Bahkan, gaya semacam ini adalah tuntutan pasar. Dan pada kenyataannya jenis tontonan semacam inilah yang mendapat rating jumlah penonton yang paling tinggi dibandingkan dengan acara-acara TV lainnya. “...Dihadapan sekitar 3000 pasang mata, mereka menyajikan suguhan menghibur. Inul yang sedang banyak menuai kritik terlihat tanpa beban bergoyang ngebor..."11 Acara yang banyak menyedot perhatian penonton inilah yang kategorikan sebagai acara yang sukses. Pada gilirannya

\footnotetext{
${ }^{9}$ Jawa Pos edisi 25 April 2006

10 ibid

${ }^{11}$ Jawa Pos edisi 19 Mei 2006
} 
program/ acara yang sukses tersebut berdampak penciptaan income sebesar-besarnya. Sehingga program/ acara tersebut kemudian dirancang berkelanjutan. Dalam hal ini, sering kali produser tidak peduli terhadap :dampak (positif/ negatif) dari setiap acara yang disiarkan. Prinsip mereka “The show must go on!" manakala acara itu laku keras di pasar dan bisa menghasilkan income sebanyak-banyaknya.

Biasanya untuk acara-acara TV yang mendapat rating jumlah penonton yang banyak juga akan diselingi dengan berbagai produk iklan. Dan semakin menarik sebuah acara semakin banyak pula jumlah penontonnya. Hal ini tentu saja memudahkan produser acara untuk mencari sponsor acara tersebut. Sponsor/ pendukung acara umunya dari kalangan bisnis yang punya kepentingan dengan promosi produk yang mereka jual. Dan biasanya, promosi produk / iklan itu diselipkan diantara acara/ program tertentu yang bisa banyak menyedot perhatian publik. Dengan begitu, semakin diminati suatu acara, pihak sponsor / pengusaha tidak akan ragu untuk merogoh kocek mereka untuk mendukung acara tersebut.

Setiap acara yang menarik cenderung melibatkan wanita didalamnya. Kecantikan, keindahan, kemolekan dan pesona para wanita 'cantik' itu akan dipertontonkan ke publik sesuai skenario yang ada. Karena alasan skenario dan tuntutan kesuksesan sebuah acara, seorang aktris dintuntut untuk tampil "maksimal". Walau kadang-kadang, untuk memenuhi unsur profesionalitas itu, mereka harus berurusan dengan pihak yang berwajib terkait dengan pornografi/ pornoaksi. Tetapi guna alasan profesionalitas, hal tersebut bukanlah masalah besar bagi mereka. "Oktavini Gunawan, setelah diperiksa selama hampir empat jam, Ika begitu sapaan akrabnya nggak nyesal berpose dimajalah Playboy, "Nggak kapok - kenapa harus kapok? Saya menjalankan profesi saya sebagai model," ujarnya. "Gadis yang berdomisili disorong tersebut tidak menyesal sudah berpose sebagai Miss April dimajalah Playboy Indonesia. Pose-posenya itu hanyalah sebagian tugasnya sebagai seorang model profesional." 12

Ukuran masksimalitas sebuah acara inilah yang menjadi sebuah bukti nyata akan eksploitasi wanita. Tetapi, lebih parah lagi, dalam kenyataannya sang artispun tidak berdaya menolak tawaran sang produser yang sanggup memberikan "iming-iming” bonus yang tinggi. Dan selama produser membayar sesuai kontrak yang ada, tuntutan skenario/ profesionalisme biasanya bukanlah menjadi masalah bagi sang artis.

Sebenarnya selain program-program TV, banyak media lainnya yang juga menonjolkan kesan feminin yang berlebihan dan cenderung vulgar pada perempuan. Salah satunya adalah majalah Playboy. Majalah 'Barat' ini seringkali menyuguhkan gambar-gambar wanita yang hanya dibungkus dengan pakaian yang serba sangat minim dan dengan gaya yang sangat menantang sehingga menonjolkan kesan feminin yang berlebihan yang mengarah pada "Pornografi/ Pornoaksi". Dalam Encyclopedia Britannica disebutkan "Pornografi adalah representasi dari perilaku erotis, seperti dalam buku-buku, gambar atau film, yang dimaksudkan untuk menimbulkan rangsangan seks. Pornografi telah dilarang dalam UU disebagian besar negara paling tidak atas dasar salah satu asumsi sebagai berikut: (1) Pornografi cenderung merusak moral kaum muda, atau

\footnotetext{
${ }^{12}$ Jawa Pos edisi 27 April 2006
} 
orang dewasa dan pemuda; dan (2) Konsumsi materi-materi pornografi menyebabkan timbulnya kejahatan seksual. ${ }^{13}$

Sehingga segala hal yang berbau pornografi inilah yang gampang menimbulkan rangsangan seks, yang lebih jauh akan berdampak pada kejahatan seksual. Dalam kaitannya dengan tampilan wanita yang cenderung sangat erotis dan vulgar yang ada di majalah Playboy, dunia hiburan, atapun bidang bisnis lainnya, sadar atau tidak sadar, sebenarnya kaum wanita telah dieksploitasi sedemikian rupa demi kepentingan bisnis kaum kapitalis.

\section{Wanita Bagi Kaum Kapitalis}

Dalam sistem kapitalisme kekuasaan ada ditangan pemegang kapital/ modal. Mereka ini yang disebut sebagai kaum kapitalis. Setidaknya ada tiga hal penting yang dipakai oleh kaum kapitalis dalam memacu keberhasilan usaha:

1). Kemandirian (individualisme);

2). Persaingan (competition);

3). pengerukan keuntungan (profit oriented).

Kemandirian/ individualisme sangat penting peranannya dalam kapitalisme. Disini individu harus melihat dirinya bukan bagian dari masyarakat melainkan sebagai individu yang harus berjuang sendiri untuk memenuhi kebutuhan hidup dan keberhasilannya. Dalam konteks ini individu dalam sistim kapitalisme bisa berbentuk manusia/ individu, institusi, perusahaan, ataupun suatu bangsa. Keunggulan kaum kapitalis diperlihatkan dalam bentuk keunggulan berproduksi. Untuk itu diperlukan kemampuan berkompetisi antar individu. Dan bagi yang sukses dalam persaingan akan tetap bertahan hidup. Sedang bagi yang lemah akan tersingkir dan mati. Konsep ekonomi mereka adalah bentuk ekonomi bebas, meliputi segala produk yang dikonsumsi, dan tanpa batas, cakupannya lintas negara, dan dengan menggunakan modal sekecil-kecilnya untuk mendapatkan keuntungan yang sebesar-besarnya. ${ }^{14}$

Sementara itu, suatu masyarakat kapitalis, Menurut Marx, adalah suatu masyarakat yang menganut sistim ekonomi pasar bebas. Kapitalisme bisa menciptakan dua kelas di masyarakat yaitu kaum Borjuis (pemilik modal) dan kaum proletar (buruh). Dia mengartikan dua kelas ini dalam kaitannya dengan hubungan mereka yang berbeda dalam alat-alat produksi. Alat-alat produksi adalah segala sesuatu selain tenaga manusia yang menghasilkan kekayaan. Alat-alat produksi yang paling utama antara lain lahan/ tanah (tempat tanaman tumbuh, beternak, lokasi bangunan/ gedung), mesin-mesin dan peralatan, dan modal investasi. Kelas Borjuis memiliki alat-alat produksi ini. Sedangkan kaum proletar tidak memiliki alat-alat produksi ini dan oleh karena itu mereka harus menjual 'kemampuan/ tenaga' mereka kepada kaum borjuis. ${ }^{15}$

\footnotetext{
${ }^{13}$ Suwarsono, Perubahan Sosial dan Pembangunan. Jakarta: Pustaka LP3ES (1994)

${ }^{14} \mathrm{http} / / / \mathrm{ww} . j a c q u e s . c o m / d e f i n i t i o n /$ kapitalisme.htm.

15 Rodney Stark, Sociology. California: Wadsworth Publishing Company (1994)
} 
Dari kutipan diatas jelas bahwa sistem kapitalisme telah menciptakan terjadinya kelas dalam masyarakat yaitu kaum borjuis (pemilik modal) dan kaum proletar (buruh). Kaum kapitalis adalah kaum borjuis (pemilik modal). Guna mengembangkan modal dan melanggengkan kursi kekuasaannya, kaum kapitalis memerlukan sebuah media usaha/ bisnis. Bisnis yang mereka geluti bermacam-macam dan bahkan ada disetiap aspek kehidupan. Untuk mencapai keberhasilan dalam kegiatan bisnis mereka, kaum kapitalis tidak berjalan setengah - setengah. Mereka bisa menggunakan berbagai macam cara untuk tujuan bisnis mereka. Hal ini juga tidak lepas dari prinsip yang mereka miliki: kemandirian/ kerja keras, kemampuan bersaing bebas, dan berusaha mengeruk keuntungan sebanyak-banyaknya.

Kapitalisme sendiri lahir sebagai akibat dari revolusi industri. Dan penggunaan kapital yang tepat disektor industri akan memperbesar kursi kekuasaan kapitalisme. Untuk itulah kapitalisme menciptakan sebuah budaya baru. Budaya baru ini disebut sebagai budaya pop (pop culture). Morris menyatakan bahwa budaya pop adalah suatu 'marketing category'. Dalam hal ini sebuah bentuk produk yang dijual sebagai hiburan, sebagai kesenangan, sebagai bagian yang 'dinikmati' dari pada 'untuk kebaikan' orang. Oleh karena itu budaya pop identik dengan koran - tabloid, dan karya fiksi (cerita roman, cerita fiksi, cerita detektif, cerita/ film barat) dari pada cerita klasik. Beberapa jenis musik tertentu seperti 'rock'n'roll, rao, disco-funk juga dikategorikan sebagai bagian dari budaya pop tetapi untuk musik klasi dan opera bukan. Begitu juga untuk film-film populer dan juga produk TV adalah bagian dari budaya pop. ${ }^{16}$

Budaya pop ini nantinya akan menjadi mesin yang amat sangat produktif bagi kaum kapitalis. Kaum kapitalis bahkan menyebut budaya pop ini sebagai suatu budaya yang beradab, modern dan tidak ketinggalan jaman. Dengan demikian segala hal diluar budaya pop dikategorikan sebagai sesuatu yang ketinggalan jaman (out of date). Banyak masyarakat "awam” yang dibikin terperangah oleh kemunculannya. Dampaknya, merekapun kemudian beramai-ramai memakai ataupun meniru segala hal yang berbau pop culture. Itu mereka lakukan karena mereka tidak mau jika didalam pergaulan, gara-gara tidak memakai produk pop culture, mereka dicap sebagai individu yang kuno, tidak modern dan lebih parah lagi primitif dan tidak beradab. Inilah kehebatan kaum kapitalis. Untuk melanggengkan kekuasaannya, mereka akan melakukan apa saja. Dan salah satunya adalah dengan menciptakan sebuah budaya baru yaitu budaya pop yang mereka simbolkan sebagai puncak modernitas/ mode dan juga peradaban.

Budaya pop (Pop Culture) benar-benar merupakan kepanjangan tangan dari kapitalisme yang sangat efektif dan produktif. Budaya pop adalah nilai-nilai yang berasal dari industri hiburan, iklan,media dan simbol mode yang ditujukan untuk masyarakat awam. Sehingga budaya pop ini sering juga diartikan sebagai budaya massa. Bahkan ada pula yang menyebutnya sebagai budaya komersial. Budaya pop ini paling tidak memiliki 2 ciri pokok: ${ }^{17}$

\footnotetext{
16 Anne C Francis. Popular Culture. Victoria: Deakin Univ. Press (h.6; 1994)

${ }^{17}$ (http:/first-thing-first.blongspot.cm/2005/01/menyimak-budaya-populer.htm.)
} 
1. Bersifat instant: memberikan kepuasan sesaat, pasif, dan cenderung dangkal.

2. Bersifat massa: sangat mudah menyebar di masyarakat.

Menurut Raymond William, budaya pop memiliki 3 arti:

1. Disukai oleh banyak orang

2. Tidak punya nilai (film tentang pornografi, perkosaan,ddl)

3. Hanya digunakan untuk hiburan/ menghibur

Salah satu sifat manusia adalah suka akan hiburan. Ini pula yang kemudian menjadi dasar philosofis dalam bersastra. Bahwasannya sebuah karya sastra yang bagus harus mengandung unsur dulce et utile (menghibur dan bernilai). Sehingga sebuah karya yang "apik" harus bisa menghibur disatu fihak dan memberikan sebuah pencerahan (batin) dilain pihak. Dan inilah kehebatan kaum kapitalis. Rupanya kaum kapitalis sadar/ tidak sadar telah pula mengadopsi prinsip philosofis dalam bersastra, dulce et utile, kedalam bisnis mereka. Namun bukan dua-duanya yang mereka ambil. Tetapi mereka hanya mengambil prinsip dulce (menghibur) yang sesuai dengan prinsip bisnis mereka. Bagaimana dengan utile? Utile mungkin tidak begitu penting bagi kaum kapitalis. Mengapa? Hal ini karena sesuatu yang bernilai belum tentu laku dipasar. Sehingga hal tersebut bisa mereka kesampingkan. Morris menyatakan bahwa tujuan dari budaya pop adalah bagi keberhasilan pasar. Sehingga semua hal yang menghambat kelancaran bisnis walaupun bernilai estetis akan dikesampingkan. Dan bisnis hiburan, iklan, media dan simbol mode adalah bisnis yang dalam arti luas sudah menyangkut setiap aspek kehidupan manusia sudah mereka geluti selama ini. Sekali lagi tujuan utama bisnis mereka adalah untuk mendapatkan laba yang sebesar-besarnya. Sehingga dalam berbisnis mereka memang tidak berusaha memberikan sebuah pencerahan tetapi bagaimana menampilkan sebuah bisnis/ hiburan yang murah, diterima/ disukai banyak orang, instant, 'tidak bernilai' dan dapat menghasilkan keuntungan yang sebesar-besarnya bagi mereka.

Di berbagi media di Indonesia, sekarang ini gampang sekali dijumpai kegiatan-kegiatan yang sifatnya hanya menghibur tadi. Mulai dari TV, majalah, bioskop, radio, internet, dll. semua media ini hampir bisa dipastikan menawarkan hiburan sebagai salah satu program mereka. Acara hiburan itu dibuat sedemikian rupa sehingga terkesan ringan/ tidak perlu memeras otak untuk menikmatinya, massal/ bisa diterima orang banyak, menimbulkan kepuasan sesaat, dan tujuannya benar-benar untuk menghibur. Acara-acara musik dangdut, pop, sinetron, film dan banyak acaraacara lainnya yang menampilkan adegan peluk cium, joget penyanyi/ gaya artis yang cenderung seksi dan bahkan erotis di beberapa stasiun TV, gambar-gambar wanita setengah telanjang dengan gaya yang sangat seksi dan menantang yang hanya ditutupi oleh beberapa helai kain yang sangat tipis di majalah (Playboy), adalah acara/ program yang tampaknya sekarang sedang menjadi trend. Bagi kaum bisnis jenis tontonan semacan ini yang akan mendatangkan banyak keuntungan. Sehingga mereka terus saja bergairah menghasilkan produk-produk yang serupa.

Tentu saja dalam membuat acara seperti itu, pihak produser/ kaum kapitalis telah mempersiapkan sebuah skenario/ aturan main yang "harus" diikuti para wanita ( artis/ penyanyi/ model, dll.) yang akan mereka libatkan dalam suatu bisnis. Kaum kapitalis juga telah memperhitungkan matang-matang laba/ rugi yang akan mereka terima. Dan tentu saja mereka tidak 
mau rugi. Oleh karena itu, seorang pemilik modal akan memaksa sang wanita (artis/ penyanyi/ model, dll.) untuk bermain maksimal. Istilah yang mereka pakai adalah "profesional".

Karena alasan profesionalisme/ maksimaliltas ini, sang artis 'harus' melakukan gaya/ adegan apapun demi keberhasilan sebuah program/ acara. Hal ini dikarenakan mereka juga sudah terikat oleh sebuah kontrak kerja yang sudah dipersiapkan oleh kaum pengusaha. Dan biasanya kontrak kerja itu berkekuatan hukum. Sehingga para artis/ model/ penyanyi, dll. tidak bisa berbuat semau mereka sendiri. Mereka menjadi tidak berdaya/ berkutik terhadap kemauan sang produser/ pemilik modal. Dengan demikian, apapun yang diinginkan oleh kaum kapitalis mereka akan melakukannya.

Seorang artis seringkali berkilah bahwa apa yang mereka lakukan adalah cerminan dari sikap profesional yang mereka miliki. Namun manakala mereka harus mengikuti aturan main/ skenario yang ada yang telah dipersiapkan oleh kaum kapitalis, apakah kata "PROFESIONALISME" masih berlaku? Apakah yang mereka lakukan itu bukanya lebih dari sebuah KETERPAKSAAN PROFESI karena ketidak berdayaan mereka terhadap para pemilik modal dari pada SIKAP PROFESIONAL pada bidang kerja mereka?

Dalam perspektif kapitalis, apakah yang dilakukan kaum kapitalis kepada kaum buruh itu adalah suatu hal yang salah? Untuk menjawab pernyaan ini, kita harus me-'review' kembali filsafat kaum kapitalis bagi pengembangan usaha mereka, yaitu kemandirian, semangat kompetisi dan juga semangat untuk mengeruk keuntungan yang sebesar-besarnya. Prinsip-prinsip tersebut telah menjadi denyut nadi bagi kaum kapitalis. Mereka tidak akan hidup manakala denyut itu berhenti. Dan dengan kerasnya persaingan hidup di era globalisasi yang menganut sistem free market (pasar bebas) dewasa ini, eksistensi individu akan diuji. Tak terkecuali kalangan kapitalis.

Dalam sistim pasar bebas, iklim usaha ditentukan oleh pasar.Tidak ada campur tangan dari pemerintah. Jadi keberhasilan usaha kaum kapitalis ditentukan oleh mereka sendiri. Sehingga mereka harus bisa membaca kebutuhan pasar. Setelah itu, mereka juga harus tahu mengenai produk apa yang akan mereka hasilkan dan selanjutnya mereka jual. Pada saat yang sama, mereka selalu melakukan analisis nilai jual sebuah produk dan juga daya beli masyarakat terhadap sebuah produk di pasar. Jika produk yang mereka hasilkan laku keras dipasar dan diminati orang banyak, maka mereka akan memproduksi produk secara massal. Untuk itu, mereka akan melakukan segala cara semi suksesnya launching produk tersebut. Kaum kapitalis melakukan ini semua secara cermat. Dengan modal yang mereka miliki, ditengah persaingan bisnis yang begitu ketat, untuk menjaga eksistensi mereka maka mengemas produk yang mereka jual sedemikian rupa adalah sebuah keniscayaan. Segala cara dilakukan guna menghasilkan sebuah produk yang nantinya diminati oleh konsumen. Hal ini sejalan dengan pendapat Kottak menyatakan bahwa perekonomian kapitalis didasarkan pada produksi bagi penjualan dengan tujuan utama untuk mendapatkan keuntungan yang sebesar-besarnya.

Cara mengemas produk yang kreatif dan inovatif (konteks kapitalis) agar menjadi sebuah produk yang menarik dan mempunyai nilai jual tinggi dilakukan dengan bagai cara. Dalam bisnis hiburan seperti majalah (Playboy), musik (dangdut/ pop), film, sinetron, fashion, dilakukan dengan 
menyuruh artis/ penyanyi untuk mengikuti skenario yang telah disiapkan oleh sang produser. Untuk ini, si artis/ penyanyi seringkali 'terpaksa' harus mengikuti aturan main dari 'tuannya'. Skenario yang ada dapat berupa gaya berpakaian yang cenderung sangat seksi dan menantang, jogetan yang cenderung erotis, dan gaya ber-'acting' yang banyak melibatkan adegan peluk-cium pria dan wanita, dll yang seronok/ vulgar dan lebih jauh dapat membangkitkan nafsu birahi/ cenderung bersifat merangsang bagi yang menontonnya.

Dalam kenyataannya jenis acara/ program yang sanggup membuat penonton terbius semacam inilah yang banyak diminati, walaupun pada saat yang bersamaan acara tersebut menuai 'protes' sana-sini. Namun bagi kaum kapitalis, kontroversi semacam ini bukanlah masalah besar. Bahkan mereka sangat mendapatkan keuntungan akan adanya kontroversi. Sebab dengan begitu akan menjadi lebih jelas bahwa ditengah badai 'protes', apa yang mereka produksi ternyata ada peminat/ pendukungnya. Badai protes terhadap produk mereka secara tidak langsung juga menjadi salah satu cara yang produktif bagi promosi sebuah produk/ barang yang mereka hasilkan.

Jadi di era global yang menganut sistem pasar bebas seperti sekarang ini, pemanfaatan wanita oleh kaum kapitalis adalah sebuah keharusan. Wanita tersebut mereka jadikan bagian objek dari sebuah produk yang selanjutnya mereka jual kepasar. Hal ini merupakan salah satu cara yang dipakai oleh kaum kapitalis untuk menjaga kelanggengan/ kepentingan bisnis yang mereka. Dan kesemuanya itu masih dalam kerangka filosofis kaum kapitalis untuk tetap mandiri, mampu bersaing dan mendapatkan keuntungan yang sebesar-besarnya.

Eksploitasi wanita sendiri, sebenarnya telah lama berlangsung bahkan sejak jaman kerajaan Romawi. Dan lagi-lagi dalam hal ini kaum pekerja dibuat tidak berkutik oleh kaum kapitalis sebagai pemilik modal. Mau tidak mau mereka harus menuruti keinginan kaum kapitalis sebagai pemilik modal. Dalam hal ini, mereka sudah mendudukkan diri mereka sebagai 'budak' dan sang pemilik modal sebagai 'tuan'. Wallerstain menunjukkan keterkaitan antara timbulnya kapitalisme dengan industrialisasi. Ia menggunakan istilah kapitalisme jauh lebih luas. Ia mempertanyakan mengapa ada cara-cara organisasi tenaga kerja yang berbeda-beda - perbudakan, feodalisme, pekerjaan gajian,...itulah sebabnya mengapa perbudakan dapat berkembang dikerajaan Romawi dan mengapa hal itu merupakan lembaga kapitalis yang sangat cocok sesuai dengan tahap-tahap permulaan praindustri, suatu ekonomi dunia yang kapitalis...bagi seorang Marxist, dimana ada kapitalisme disitu ada eksploitasi...eksploitasi terjadi disemua masyarakat dimana orang dibagi menjadi dua kelas yang saling berlawanan, sebagai tuan dan budak, tuan dan pekerja, atau pemilik kapital dan buruh. ${ }^{18}$

Posisi kelas tuan/ majikan - buruh/ pekerja yang di timbulkan dalam sistem kapitalisme semakin mempermudah eksploitasi kaum kapitalis terhadap kalangan buruh yang tidak berdaya. Teresa Hayter juga menyatakan bahwa kebijakan konvensional merupakan 'suatu bangunan tipu daya yang kompleks' dan bahwa bantuan itu sendiri hanya dapat dijelaskan sebagai 'usaha untuk

\footnotetext{
${ }^{18}$ J.E.,Goldthorpe, Sosiologi Dunia Ketiga. Jakarta: PT. Gramedia(h.224; 1992)
} 
mempertahankan sistem kapitalis didunia ketiga'. Karena kapitalisme harus diidentifikasikan sebagai eksploitasi dan dependensi. ${ }^{19}$

Dan karena kaum kapitalis telah membeli tenaga mereka, mau tidak mau kaum buruh 'harus' menuruti kehendak sang pemilik modal. Mereka tidak punya pilihan lain. Hal ini senada dengan penyataan Suwarsono yang menyatakan "kapitalisme sebagai sitem yang berdasarkan pada persaingan bebas, persaingan antara produsen untuk menggunakan tenaga kerja dan juga tidak terikat untuk menghasilkan produk yang dikehendaki...Dalam model ini pemilik modal membeli kemampuan tenaga kerja tersebut. Dengan membayarnya dalam bentuk upah kepada pekerja yang sama sekali tidak memiliki pilihan lain dalam hidupnya"

\section{Kesimpulan}

Di era global yang menganut sistem pasar bebas dengan persaingan usaha yang amat sangat ketat seperti sekarang ini, memanfaatkan wanita (dengan penampilan/ gaya yang sangat seksi dan menantang seperti dalam majalah Playboy dan bisnis hiburan lainnya) dan menjadikan mereka sebagai objek dari sebuah produk yang selanjutnya dijual kepasar hanyalah merupakan salah satu cara yang dipakai oleh kaum kapitalis untuk menjaga kelanggengan/ kepentingan bisnis yang mereka. Eksploitasi wanita itu sendiri, sebenarnya telah lama berlangsung bahkan sejak jaman kerajaan Romawi. Dan lagi-lagi dalam hal ini kaum pekerja (sebagian besar wanita) dibuat tidak berkutik oleh kaum kapitalis sebagai pemilik modal. Sistem kapitalisme telah menciptakan adanya dua kelas yang saling berhadapan yaitu kaum pemilik modal dan kaum pekerja/ buruh. Dan dalam sebuah sistem produksi, mereka sudah mendudukkan diri mereka sebagai 'budak' dan sang pemilik modal sebagai 'tuan'. Dalam hal ini, wanita, sebagi bagian dari kaum pekerja/ buruh mau tidak mau harus menuruti keinginan kaum kapitalis sebagai pemilik modal. Dengan melakukan apa-apa yang diingikan oleh kaum kapitalis, pada prinsipnya mereka/ kaum buruh telah menjual 'segala kemampuan' mereka. Dan dengan melakukan itu semua mereka agar mendapatkan 'upah'. Jadi pada dasarnya pemanfaatan wanita (eksploitasi wanita) pada setiap bisnis yang digeluti oleh kaum kapitalis hanyalah merupakan salah satu cara kaum kapitalis agar tetap mandiri, mampu bersaing dan mendapatkan keuntungan yang sebesar-besarnya 


\section{Daftar Pustaka}

Bank Indonesia. 2005. Kajian Ekonomi Regional Propinsi Jawa Timur. Surabaya: Bank Indonesia Surabaya Bidang Ekonomi Moneter.

Francis, Anne C. 1994. Popular Culture. Victoria: Deakin Univ. Press

Goldthorpe, J.E. 1992. Sosiologi Dunia Ketiga. Jakarta: PT. Gramedia

Jawa Pos. Edisi 25 April 2006

Jawa Pos. Edisi 27 April 2006

Jawa Pos. Edisi 8 April 2006

Jawa Pos. Edisi 19 Mei 06

Jawa Pos, Edisi 8 Juli 06

Kompas. Edisi 23 April 2006

Republika. Edisi 17 April 2006

Kottak, Conrad P. Anthropolgy: The Exploration of Human Diversity. New York: McGraw-Hill, Inc.

Stark, Rodney. 1987. Sociology. California: Wadsworth Publishing Company

Suwarsono. 1994. Perubahan Sosial dan Pembangunan. Jakarta: Pustaka LP3ES

(http://ww.jacques.com/definition/kapitalisme.htm.)

(http:/first-thing-first.blongspot.cm/2005/01/menyimak-budaya-populer.htm.) 